\title{
Foucault and Spinoza: Philosophies of Immanence and the Decentred Political Subject
}

\author{
Dr James Juniper \\ School of Policy \\ University of Newcastle \\ $\&$ \\ Dr Jim Jose \\ School of Policy \\ University of Newcastle
}

Paper to be presented to the

Australasian Political Studies Association Conference

Department of Political Studies

University of Otago

Dunedin

New Zealand

28 - 30 September 2005 


\title{
Foucault and Spinoza: Philosophies of Immanence and the Decentred Political Subject
}

\begin{abstract}
Over the last few decades, philosophers such as Althusser, Negri, Balibar, and Macherey have turned to the works of Spinoza as a means for re-invigorating radical political theory and practice. As Montag argues, rather than being conceived as a theory or a doctrine Spinoza's materialist philosophy of immanence is more a mode of strategic manoeuvrer through the philosophical field, rooting out all vestiges of idealism. At the same time, Spinoza is seen to anticipate The German Ideology in his notion that erroneous beliefs have an objective, determinate existence, are intelligible, and ultimately can be overcome. Moreover, in attacking Hobbesian notions of treaty on the basis of a unique theory of power, Spinoza's political philosophy already contains the seeds of a critique of the Liberal theories of contract that have yet to appear. Although Foucault's major works were also published over this same period it is hard to find the trace of any influence over them that could be sourced directly or indirectly from Spinoza. Yet Gilles Deleuze, a close friend and sympathetic traveller with Foucault through many of these years has highlighted a common concern with the notion of immanence, manifest in a shared determination to overcome the transcendental illusions of thought, including those reflected in theories of subjective intentionality and contract-based theories of State power. The objective of this paper is to highlight these shared concerns.
\end{abstract}




\section{Foucault and Spinoza: Philosophies of Immanence and the Decentred Political Subject}

Three centuries ago certain fools were astonished because Spinoza wished to see the liberation of man, even though he did not believe in his liberty or even in his particular existence. Today new fools, or even the same ones reincarnated, are astonished because the Foucault who had spoken of the death of man took part in political struggle. ... Spinoza said that there was no telling what the human body might achieve, once freed from human discipline. To which Foucault replies that there is no telling what man might achieve 'as a living being'; as the set of forces that resist (Deleuze 1999, 90, 93).

\section{Introduction}

Deleuze's positioning of Foucault and Spinoza as kindred spirits seems fanciful, even provocative. On the one hand there is Spinoza, the radical philosopher whose views offended official religions and their guardians, both for his probing analyses of their logic and his unequivocal commitment to human freedom and religious (and political) toleration. On the other is Foucault, an equally radical philosopher committed to human freedom, but who also revelled in being a trickster or shape-shifter whose philosophy appeared to deny any norms upon which liberty or toleration might be justified. Yet Deleuze's juxtapositioning of Spinoza and Foucault is not as fanciful as it might first appear.

During the two decades following May-68, radical philosophers like Macherey (1979), Negri (1991, 2004), and Balibar (1985, 1984), developed an interest in Spinoza's (1996) ethico-political thought, arguing for its relevance to contemporary political theory (Fourtounis 2005). Macherey and Balibar were one-time members of the Althusserian Circle, and Negri was associated with the Italian Autonomist Movement. This new wave of Spinoza scholarship drew upon a cluster of definitive studies that were published almost simultaneously by Deleuze (1968), Guéroult (1968), and Matheron (1969). Over the same period, Foucault wrote some of his major works including The Archaeology of Knowledge (1972), Discipline and Punish (1979a), and The History of Sexuality (1984) and The Use of Pleasure (1988). However, Spinoza's name rarely appeared within these works. For example, in The Order of Things (1970) Foucault addressed the Classical Period of the Seventeenth Century in very general, broad brush terms. Nevertheless, respectful commentators on Foucault's thinking, especially Deleuze, have highlighted themes, objectives, and targets of criticism that are seemingly shared by the contributors to this new wave of Spinoza scholarship. These common issues and concerns reflect the fact that members of this generation of philosophers were united by their engagement in what can best be described as a materialist critique of philosophical idealism: a critique that, nevertheless, attempted to surpass, or at the very least re-invigorate Marxist perspectives on the very relationship that should hold between political activism and social theory. 
The objective of this paper is to identify and articulate these shared themes, objectives, and targets of criticism through an interrogation of Foucault's works as seen through the eyes of Deleuze. We argue that Foucault's view of governmentality and its re-theorisation of power, sovereignty and resistance provides insight into how humans are constituted as individualized subjects and populations are formed as subject to specific regimes or mentalities of government, while at the same time illuminating the strategies for transforming these constituting and objectivising forces. Spinoza too was concerned with how humans organised themselves into communities capable of self-government. His distinction between constituted and constitutive power provided an alternative to the dominant ideas of his time that were invoked to justify particular forms of political rule. For Spinoza, the idea of immanent causality was crucial because central to his ideas of freedom and power. In addition to their ideas about immanent causality they both developed a view of the self that challenged the humanist idea of the self as a transcendent being. For both thinkers the subject was decentred, the "death of man" as Foucault declared in the Archaeology of Knowledge. In providing this comparison of Foucault and Spinoza we therefore also ask to what extent Spinoza's distinction between constituted and constitutive power prefigures the ideas that Foucault developed in his theory of governmentality and the latter's rethinking of power and resistance.

\section{Spinozian Insights}

Montag's (1989) lucid review of the encounter between Spinoza and the French Marxist philosophers Althusser, Balibar and Machery, argues that Spinoza's works helped this group of authors to pose previously unasked questions about Marx's philosophy. Montag also emphasises the fact that, prior to the 1970 publication of Reading Capital, few members of the group had written about Spinoza. Nor, moreover, was the precise meaning of crucial insights into the more general nature of a materialist philosophy to be fully worked out until much later: in other words, Montag suggests that the answer provided by Spinoza's philosophy could only identified after the relevant questions could be framed.

Critical to the formation of this question is the notion that materialism is not so much a theory or a doctrine but, rather, a mode of strategic manoeuvrer through the philosophical field. Montag cautions that Transcendentalism, the antagonist of this campaign, is an ever-changing apparatus. Thus, Spinoza was forced to intervene on many fronts. Accordingly, his oeuvre bears the effects of this strategic encounter to the extent that it is unfinished, turbulent, and elliptical.

Montag notes that ideology, for Spinoza, has two causes: on the one hand, ignorance of the causal chain; and on the other, the erroneous imputation of free-will and objectives to God. We overcome ideological illusions by attaining to a higher order of knowledge, which Spinoza calls knowledge of the second or third kind, the latter being of the highest order (Spinoza 1996, II, P41-2; V, P25-28). Knowledge of the first kind (opinion or imagination) obtains when we form universal notions either from singular things represented to us through the senses, but in an unordered or confused way (Spinoza calls this knowledge from random experience), and from signs or ideas of things that we have heard or read about that we recollect (Spinoza 1996, II, P40, S2). Knowledge of the
Comment [Jim1]: Do we need to return to this point in our conclusion? Our final paragraph in the Conclusion where we mention Spinoza etc does not really provide an explicit answer to the question that we claim to be asking here. 
second kind (reason) arises from common notions or adequate ideas of things; while knowledge of the third kind (intuition) proceeds from an adequate idea of the formal essence of certain attributes of God to the adequate knowledge of the formal essence of modes or things (Spinoza 1996 II, P38-40). Spinoza calls the understanding arising through the third kind of knowledge, as knowing under a species of eternity, an understanding which depends on mind, as on a formal cause, insofar as mind itself is eternal (Spinoza 1996, V, P29, P31). We take pleasure in this knowledge and our pleasure is accompanied by the idea of God as a cause (Spinoza 1996, V, P30-2). For Spinoza, this pleasure is a correlate of what he terms the intellectual love of God, which is eternal (Spinoza 1996, V, P33). Althusser and Balibar interpret Spinoza's notion of the third kind of knowledge, or the synchronic (i.e. "eternity in Spinoza's sense") in relation to Marx's notion of the "complex-real", in other words they conceive it to be the "adequate knowledge of a complex object by the adequate knowledge of its complexity" (Althusser and Balibar, 1970, 107). An anti-Hegelian quote from the Grundrisse is cited to elucidate this interpretation,

Hegel fell into the illusion of conceiving the real (das

Reale) as the result of thought recapitulating itself within itself, deepening itself within itself, and moving itself from within itself, whereas the method that allows one to rise from the abstract to the concrete is merely the mode (die Arte) of thought which appropriates the concrete and reproduces (reproduzieren) it as a spiritual concrete (geistig Konkretes) (Grundrisse der Kritik der Politischen Ökonomie, Berlin, 1953, 22)

Negri also rejects a mystical interpretation of Spinoza's conception of the third kind of knowledge. He argues that the mystical is 'cancelled out' within an ascetic and materialist celebration of collective praxis but, significantly, he argues that eternity is internal to this praxis! We know by experience that we are eternal, outside of duration. The more the mind loves God, the more perfect it is and the less it is subject to evil and fear of death. In becoming eternal it is acted on more by the second and third kinds of knowledge and, thus, a mind the greater part of which is eternal is capable of great many actions. Although the multitude is born coarse and bestial it is, however, subject to a metamorphosis through the power of community, the knowledge of God, and the plenitude of love (Negri, 2004, 209, citing Spinoza 1996, IV P68; P54).

Montag argues that the object of Spinoza's philosophical critique is 'theism', understood as a distinction between substances (either in the form of creator or creation) determined in chronological, logical, or hierarchical terms. Thus theism depends upon an ordering that has been constructed with respect to some notion of distance from origin, priority, or externality or denial of access to the eidos, the One, or God. Associated with this ordering of closeness or remoteness is a conception of knowledge as a hermeneutic reading, an unveiling of truth with respect to the more or less real, and the more or less illusory. In opposing theism, Montag cautions that Spinoza refuses a mere inversion. Instead, he constructs a notion of God or Nature as Substance and Immanent Cause, as a veritable antidote against any Platonic, hierarchical ordering. This conception of immanent causality was instrumental in over-turning the Aristotelian notion of first cause and the 
Cartesian dualism between res cogita and res extensa. For Deleuze a similar conception of immanent causality is to be found in Foucault's philosophy, a claim which now warrants closer examination.

\section{Deleuze on Immanent Causality}

In Foucault-his very personal homage to the philosopher-Deleuze highlights the role played by Foucault's idea of the 'diagram'. Deleuze conceives 'the diagram' to be an immanent cause shaping the social field insofar as it mediates between the 'visible' and the 'articulable' (ie statements) (Deleuze 1999, 33-4). Deleuze observes that what Foucault initially described in negative terms in The Archaeology of Knowledge as the sphere of non-discursive practices takes a positive form in Discipline and Punish where it is rendered as the visible. In the latter text, the diagram operates as a bridge between the two irreducible forms - visibilities through the formation and organization of matter such as in hospitals, prisons, schools, workshop, statements through the formation or finalization of functions (e.g. care, punishment, training, enforced work). In this way, the diagram 'integrates' or constitutes qualified substances (e.g. delinquents, children, soldiers, workers). For example, the abstract machinery of the Panopticon goes beyond the visual aspects of an optical arrangement for purposes of surveillance (i.e. to see without being seen) seeking to "impose a particular conduct on a particular human multiplicity" (Deleuze 1999, 34). Diagrams proliferate, they are manifest within all societies and, as interpreted by Deleuze, they escape any simple reduction either to a transcendent idea, an ideological superstructure, or to a singularly economic instance. Instead,

...the diagram acts as a non-unifying immanent cause that is coextensive with the whole social field: the abstract machine is like the cause of the concrete assemblages that execute its relations; and these relations between forces take place 'not above' but within the very tissue of the assemblages they produce (Deleuze 1999, 37).

Deleuze immediately clarifies what is at stake in his use of the term immanence, What do we mean by immanent cause? It is a cause which is realized, integrated and distinguished in its effect. Or rather the immanent cause is realized, integrated and distinguished by its effect. In this way there is a correlation or mutual presupposition between cause and effect, between abstract machine and concrete assemblages (it is for the latter that Foucault most often reserves the term 'mechanisms') (Deleuze 1999, 37).

In their book What is Philosophy Deleuze and Guattari relate immanent causality to what they call "the plane of immanence". In their view, the plane of immanence is prephilosophical insofar as it is presupposed by philosophy as a non-conceptual, intuitive understanding, not as an outside of philosophy but as philosophy's internal, instituting condition (Deleuze and Guattari 1994, 41). ${ }^{1}$ They warn that the plane of immanence is vulnerable to the "four great errors" or illusions identified by Nietzsche: (1) the illusion of transcendence (a making immanence immanent 'to' something or discovering a transcendence within immanence itself); (2) the illusion of universals (when concepts are 
confused with the plane itself); (3) the illusion of the eternal (when it is forgotten that concepts must be created); and, (4) the illusion of discursiveness (when propositions are confused with concepts) (Deleuze and Guattari 1994, 49-50) ${ }^{2}$. As such, philosophy cannot be reduced to mere contemplation, reflection, or inter-subjective communication.

Transcendence enters whenever the movement of the infinite is stopped and immanence is either (1) made immanent 'to' the One, so that another One can be superimposed over it as the One beyond the One (as in Plato where the plane becomes the concept and the Eidetic concept becomes a transcendent universal) (Deleuze and Guattari 1994, 44-6); (2) made immanent to pure consciousness or the transcendental subject (as with Descartes and Kant's Critical philosophy), or (3) something transcendent such as the Other or the Flesh is discovered within immanence itself (as with Husserl's later phenomenological enquiries where he contends that the flux lived by subjectivity does not belong entirely to that subjectivity but to an intentional object or an inter-subjectivity). Later in the same text Deleuze and Guattari argue that,

Spinoza was the philosopher who knew full well that immanence was only immanent to itself and therefore that it was a plane traversed by movements of the infinite, filled with intensive ordinates. He is therefore the prince of philosophers. Perhaps he is the only philosopher never to have compromised with transcendence and to have hunted it down everywhere. In the last book of the Ethics he produced the movement of the infinite and gave infinite speech to thought in the third kind of knowledge. There he attains incredible speeds, with such lighting compressions that one can speak only of music, of tornados, of wind and strings. He discovered that freedom exists only within immanence. He fulfilled philosophy because he satisfied its pre-philosophical presupposition. Immanence does not refer back to the Spinozist substance and modes but, on the contrary, the Spinozist concepts of substance and modes refer back to the plane of immanence as their presupposition (Deleuze and Guattari 1994, 48).

For Deleuze this Spinozian critique of transcendence can readily be seen in Foucault's critique of neo-Kantianism where emphasis is placed on the irreducibility of the two strata, statements and visibilities.

In Foucault's (1983) discussion of Magritte's famous work-This Is Not a Pipe-he establishes a non-relation between text and drawing because the statement may refer to itself in speaking of the absent pipe rather than its painted representation (Deleuze 1999, 62). This non-relation carries over to the Cartesian cogito where, for Foucault, the "I think" does not rest on the "I am" but on a pure determinable element (i.e. space-time). The conjunction between the visible and articulable is impossible because the statement refers to its own correlative object along with its conditions of enunciation while visibilities are governed by their own conditions of emergence. The statement does not 
relate to the visible (as presumed by propositional logic), and the visible is not a mute meaning that must be realized in language (as in phenomenology) (Deleuze 1999, 64).

The interlacing between the articulable and the visible is therefore established via games of truth and the various procedures for its establishment (i.e. pragmatisms of method and process, which pose questions of what is revealed in various strata and thresholds) (Deleuze, 1999, 63; citing Foucault 1984, 93-4). Foucault adopts the metaphor of war and its implicit language of strategy to characterise the ongoing dynamism of the relationship between these two irreducible strata.

Deleuze is adamant that Foucault's philosophy is opposed to Neo-Kantianism because the real is experienced on the side of the object and historical formation, not the universal subject (Deleuze 1999, 60; citing Foucault 1970, 244). While Kant appealed to the mystery of the schemata of the imagination, Foucault turns to power (Deleuze 1999, 68). Although Foucault's diagrams appear to act as bridges between spontaneity and receptivity in a manner analogous to Kant's schemata, in contrast the diagram is the historical a priori. It is the non-place of mutation because relations of forces do not lie outside strata: instead, to the extent that they form the outside of strata they are themselves historical (Deleuze 1999, 84-6).

For Foucault, power is not a form. It cannot be reduced to natural law; nor is it singular but a relation. It imposes distribution in space, ordering in time, and composition in space-time (Deleuze 1999, 70-71; citing Foucault 1979a, 231). Moreover, power is seen to be productive rather than essentially repressive, to be practiced rather than possessed. It is a force passing through other forces: both those exercised by masters and by the mastered. Power is the power to affect and to be affected, to incite, to provoke and produce or to be incited, provoked and produced. However, the practice of power is not reducible to that of knowledge. Each in relation to the other is 'mutually immanent' (Deleuze 1999, 73-4, citing Foucault 1984, 99-100). Power relations provoke forms of knowledge which may cross epistemological thresholds or institute practices. In their generality the forces and formal categories of knowledge (educating, caring for, punishing) actualise, modify, redistribute and stabilize the affective categories of power (inciting, provoking, producing) through their integrative capacity, not least through establishing various institutions (e.g. State, family, Religion, production, and the marketplace) (Deleuze 1999, 75). In this context the State achieves global integration only because it organizes relations of political rule around a central agency of Sovereign and Law, much like the family around the Father, and the market around Money and Gold (Deleuze 1999, 76-77).

\section{Resistance and the Outside of Thought}

While thinking and speaking are forms of exteriority, thinking addresses itself to an outside that has no form: it reaches the non-stratified outside situated at the disjunction between seeing and speaking. In this way, Deleuze argues, it escapes the constitutive interiority of a phenomenology, which presupposes a beginning and an end, an origin and a destination eating into the interval between words and things (Deleuze 1999, 86-7). 
Historical transformation occurs when the composing forces of stratification enter into a relation with other forces (strategies from the outside). Deleuze suggests that mutation affects these composing forces, not the composed forms associated with them. Nor is it a question of humanity as a conception, or an articulable, perceptible real unity; rather it is a question of the emergent forces that make up a human being (Deleuze 1999, 87-8).

While the diagram is seen to emerge from this outside, Deleuze contends that, for Foucault, it never exhausts its force. Nor does the outside merge with the diagram, but rather it continues to construct new diagrams that perpetually come to displace their now redundant predecessors. For this very reason, Deleuze argues that resistance "comes first" insofar as it operates in a direct relation with the outside, whereas power relations operate within the diagram (Deleuze 1999, 89, fn 28). At this stage-in a manner that resonates strongly with Negri's (1991) reading of Spinoza-Deleuze approvingly comments on the apparent traces within Foucault's thought of Mario Tronti's notion that the resistance of workers has constitutive priority over the reactive strategies of capital (Deleuze 1999, fn 28). We shall return to the notion of resistance and power below. For now we turn to the issue of technologies of self.

\section{Enkrateia and the Fold in the Outside}

In The Use of Pleasure a fourth dimension is added to that of knowledge, power and thought (Foucault 1988, 8). Foucault introduces this dimension by asking the question: If thought is the outside does that mean there is an inside, perhaps an inside deeper than any internal world? As Deleuze argues, from The Order of Things onwards the unthought is not conceived by Foucault as external to thought but as what lies at its very heart, hollowing out and doubling the outside (Deleuze 1999, 96-97; citing Foucault 1970, 327 $8 \& 339$ ). Rather than a doubling of the One, it is thus conceived as a redoubling of the Other, rather than the reproduction of the Same it is conceived as a repetition of the Different, and rather than an emanation of the ' $\mathrm{I}$ ' it is conceived as the immanence of the Non-self, a Self that lives Me as the double of the Other (Deleuze 1999, 98).

In Greek thought, the relation to oneself (enkrateia) is derived from one's relation to others, a relation that detaches itself from power relations. However, it is equally a selfconstitution derived from a moral code acting as a rule for knowledge (Deleuze 1999, 100, citing Foucault 1988, 81). It thus comes about as a relation that force has with itself, a power to affect itself. Within the philosophical universe of the ancient Greek world only free beings could dominate others but this was only possible if they could dominate themselves. This insight was crucial to the later articulation of Foucault's philosophy of power and resistance.

Via this blatantly non-Kantian fold of the outside, the three intrinsically historical ontologies of acting, knowing, and being give rise, in Foucault's work, to the three notably Kantian questions: What can I do, What do I know, What am I? As such, in thought the thinking being problematizes himself, as an ethical subject, thinking his own history (the past) only in order to free himself from what he thinks (the present), in order to think otherwise (the future): and all this is articulated in the absence of any 
transcendental subject (Deleuze 1999, 118-9). Thus emerge the three crucial questions that could be said to define Foucualt's project, namely:

- how do particular modes of conduct shape individual (and group) subjectivities (Foucault 1979a, 1984)?

- how are groups of individuals and larger populations governed (Foucault 1979b, 1982, 1997b; 2000a; 2000b)?, and

- how do individuals and groups come to collaborate or acquiesce in their subjectivation and subjection? (Foucault 1981; 1984).

These questions were central to Foucault's attempts to articulate and explore the conditions for and limits to human freedom.

\section{Power, Resistance and Freedom}

Foucault recognised that the central paradox of modernist emancipatory politics was that the philosophies of freedom or liberation counterposed to any given set of oppressive conditions all failed to recognise that their own particular political rationalities were of a piece with the very same rationalities that give rise to and sustain the oppression in the first place (Brown 1995, 7; Haas 1998, 238; Barry, Osborne, \& Rose 1996, 10). For Foucault the problem facing an emancipatory politics is to derive a logic of emancipation or a form of political reason that does not at the same time reproduce the logic or rationalities of oppression. Liberalism, Socialism or Marxism remain part of the problem because they leave undisturbed longstanding assumptions about the self, sovereignty and power (Foucault 1986a, 121). Despite obvious, but significant, surface differences these influential political philosophies presuppose very similar views about political rule and the epistemological and ontological conditions for its exercise.

As we have demonstrated, Foucault rejected all philosophical perspectives that invoked particular forms of transcendence, in particular the idea of a transcendent self (of a sovereign consciousness), and associated with these conceptualisations of power as negative, repressive, or juridically focused. His aim was to develop an understanding of subjectivity and power that would inform an emancipatory politics (Foucault 2000d; 1982).

Foucault denied two crucial commonplaces of political thought: one, that there was a singular locus of power that could be contested and countered by those who were subject to specific rules of power, and two, that there were specific singular principles that organise such resistance. In his view, acts of resistance generally were not singular instances of binary oppositions or antinomies, but rather were multiple, mobile and transitory. Resistances were "the odd term in relations of power; they [were] inscribed in the latter as an irreducible opposite" (Foucault 1984, 96). Foucault did not deny the possibility of a revolutionary eruption, but he accounted for this by suggesting that the relevant multiple points of resistance come to be codified in much the same way as "the state relies on institutional integration of power relationships" (Foucault 1984, 96). However, for his critics prior to his writings on governmentality, he never explained in a convincing way how or why resistances came to be "inscribed" as "irreducible opposites", as immanent within relations of power. In a number of places Foucault merely asserted the reality of resistance: specifically that "there are no relations of power 
without resistances" (Foucault 1986b, 142), that "where there is power, there is resistance" (Foucault 1984, 95), that resistances "are all the more real and effective because they are formed right at the point where relations of power are exercised", and that resistance "exists the more by being in the same place as power" (Foucault 1986b, 142). Power relations depend "on the multiplicity of points of resistance" which "are present everywhere in the power network" (Foucault 1984, 95). Indeed, Foucault went so far as to claim that "if there was no resistance, there would be no power relations" (Foucault 2000c, 167; 2000d, 292). Resistance was the irreducible ontological condition for the exercise of power relations.

In his pre-governmentality approach resistance seems to be positioned as the reactive pole - its position inscribed within these force relations. As Thompson has suggested, Foucault sets up "the agenda of resistance" as always

determined by its engagement with an ascending force; its only options are to comply with or refuse the challenge. No room is left for a concept of action without an object directly instigating it, what Foucault came to call the "intransitivity of freedom" (Thompson 2003, 120).

Thompson suggests that Foucault's "force relations" model left Foucault with no space for "critical resistance" to assist in the process of "self-formation" (Thompson 2003, 120). The Deleuzian analysis of resistance raises doubts about this view. Thompson certainly pushes the point too far when he suggests that Foucault's writings on governmentality represent a "fundamentally new conception of power" (Thompson 2003, 120). Rather, Foucault refined his understanding of power relations (and resistance) through the development of the idea of 'governmentality'.

While still concerned with the diverse ways in which power might manifest itself, Foucault developed his idea of governmentality by posing two key questions: "By what means is power exercised?' and 'What happens when individuals exert (as they say) power over others?"” (Lemke 2002, 51). By attending to the specific means of exercising power Foucault aimed to go beyond both the juridical and the broad thrust of his own strategic approach. He did not abandon the terminology of 'strategy' and 'tactics', nor did he ignore the possibility that the exercise of power could involve violence as well as consent. However, he was more concerned with reconceptualising power as "a total structure of actions brought to bear upon possible actions"; a "set of actions upon other actions" (Foucault 1982, 789), a view that can also be found throughout Discipline and Punish and the first volume of the History of Sexuality. For Foucault the exercise of power should be understood as the means for "guiding the possibility of conduct and putting in order the possible outcome" (Foucault 1982, 789; 1993; 2000d), a process which various scholars have summed up as "the conduct of conduct" (eg Lemke 2002, 50; Rose 1999, 3; Dean 1999, 13). In short, power, as "a mode of action upon the actions of others" is government, but governing in a very much broader sense than had come to be accepted by scholars in their analyses of modern forms of government. For Foucault, the idea of 'government' needed to be returned to its older, more expansive meaning as the guiding of conduct in spheres other than the so-called political - such as "the 
government of children, of souls, of communities, of families, of the sick" (Foucault 1982, 790; 1997b 156).

Government embraced the management of "the complex unit constituted by men and things"; specifically

men in their relations, their links, their imbrications with those other things which are wealth, resources, means of subsistence, the territory with its specific qualities, climate, irrigation, fertility, etc; men in their relation to that other kind of things which are customs, habits, ways of doing and thinking, etc; lastly, men in their relation to that other kind of things again which are accidents and misfortunes such as famine, epidemics, death, etc (Foucault 1979b, 11).

On this interpretation of 'government', the reference point for the "art of government" is shifted to the management of populations and their constituent individual members. Foucault coined the term 'governmentality' the better to capture these shifts in the "art of governing". He was quite clear that he was naming a shift rather than a beginning (Foucault 1997b, 156), but his primary objective in naming 'governmentality' was to mark a clear separation between two concepts that have come to be used somewhat interchangeably: 'government' and 'State'. In his view the "relations of power [were] much more deeply implanted than at the level of superstructures" and that although "the question of the foundation of power might be important" he was adamant that "power isn't dependent on its foundation" (Foucault 1997a, 155).

Moreover, as Lemke has pointed out, the concept of 'governmentality' enabled Foucault to emphasise two key themes. First, the joining up of the idea of government and modes of thought (ie mentalities) underlined the key point for Foucault that any analysis of technologies of power, of the how of power, necessarily presupposes that "the political rationality underpinning them" must likewise be analysed (Lemke 2002, 50; 2001, 191). Second, insofar as 'governmentality' embraced a wider sense of 'governing', as noted above, it draws attention to "the close link between forms of power and the processes of subjectification" (Lemke 2002, 50; 2001, 191). Thus Lemke concluded that 'governmentality' enabled Foucault to link "technologies of the self with technologies of domination, the constitution of the subject to the formation of the state" and yet at the same time differentiate "between power and domination" (Lemke 2002, 51; esp Foucault 1993). Finally, Foucault insisted on the necessity of freedom, its "intransigence", as a constitutive feature of the art of governing (Foucault 1982, 790), a point to which we now turn.

In the Deleuzian interpretation of Foucault resistance, as an expression of the "fold in the outside", is responsible both for the transformation of diagrams and the introduction and application of new technologies of self. Similarly, these concerns are captured in Foucault's idea of governmentality with its emphasis on the arts or techniques of governing. Thus, for Foucault, "when one defines the exercise of power as a mode of action upon the actions of others" (ie as government in the broadest sense) then one must 
of necessity include resistance as an exercise of freedom (Foucault 1982, 790; 1993, 2034; 2000d, 292). Thus

power is exercised only over free subjects, and only insofar as they are free. By this we mean individuals or collective subjects who are faced with a field of possibilities in which several ways of behaving, several reactions and diverse comportments, may be realized.

... [A]t the very heart of the power relationship, and constantly provoking it, are the recalcitrance of the will and the intransigence of freedom (Foucault 1982, 790).

This same notion of resistance is mirrored in Foucault's subsequent concerns with "the care of the self", with theorising the capacity of subjects to form themselves in ways that will empower them to resist or refuse "the type of individuality that has been imposed on us for several centuries" (Foucault 1982, 790). But the individuality here is not one of some transcendent self or sovereign consciousness. Rather, what is called forth is a self that has to render itself visible to it self, so that it becomes capable of knowing itself both as it is and as it might be (Foucault 2000d, 300-01)

\section{Conclusion}

In Foucault's view the problem to be solved does not concern the dissolution of power, or even of power relations, but that of domination - by which he meant the asymmetrical structuring of power relations in which one or more subjects limit in various ways the choices or conduct available to others in the relationship (Foucault 2000d, 292). Hence it is not the generic manifestation of asymmetrical power relations but the specific form that they might take in any given social and political context. In a clear tilt at Habermas (and in contradistinction to the claims of Dupont \& Pearce 2003, 133) Foucault argues that we should not "try to dissolve [power relations] in the utopia of completely transparent communication but" to develop practices of freedom and resistance that would "allow us to play these games of power with as little domination as possible" (Foucault 2000d, 298).

Contrary to arguments (eg Dupont and Pearce 2001) that Foucault's work on governmentality reinvokes the very humanist centres of gravity that were the object of critique in his early works (eg Foucault 1970; 1972; 1973) we have suggested that Foucault's approach did not reinvoke the idea of the sovereign subject as the conscious, intentional, self-reflective agency of its development. Nor does Foucault subscribe to a neo-Hegelian, transhistorical logic in which, according to Dupont and Pearce $(2001,133)$ "an idea develops, confronts material obstacles, grows by overcoming and transcending them, to fully and finally realize itself in a particular social order". While he certainly made use of the discursive pronouncements of government officials and bureaucrats he did not suggest that 'governmentality' was the outcome of their intentions. Rather, much like his analysis of the rise of disciplinary techniques, these pronouncements emerged piece-meal in response to particular needs and, only gradually, for the most part at least, did they accumulate to the point where they could be seen as something like a "blueprint of a general method" (Foucault 1979a, 138-9). 
Furthermore, while Foucault's concept of governmentality can be associated with an idea of 'sovereignty', this is a conception that is always contingent rather than inevitable or a matter of necessity. The relations of power through which subjects, rulers, government, and the state are constituted and reproduced are not permanently fixed but are open to some degree of challenge and at times, transformation. It is not that power implies resistance in some mechanical sense (as might be concluded from a superficial reading of Foucault's earlier conception of power relations), but that for Foucault one cannot logically exercise "the conduct of conduct" without there also being possibilities of choice for those whose conduct is in question, whether it be one's own conduct or that of others. Freedom in some degree must always be present.

In this paper we set out to identify to identify and articulate the themes common to recent philosophical interpretations of Spinoza and their resonance with similar themes in Foucault's work. We argued that Foucault's re-theorisation of power, sovereignty and resistance in his later writings on governmentality provides insight into how humans make of themselves subjects (individually) at the same time as subjecting themselves (as a population) to specific regimes or mentalities of government. At the same time we have taken seriously Deleuze's insight into the continuities between these ideas and those expressed in Foucault's earlier work on discourse and discipline. In those works Foucault was concerned to demonstrate the irreducibility of the 'visible' and the 'articulable'. On this approach power operates within the diagram whereas resistance comes from the outside of thought. We have identified or highlighted the isomorphism between this Deleuzian insight and the way in which Foucault's concept of governmentality brings together four crucial dimensions: the link between the idea of government and modes of political rationality; the relationship between forms of power and processes of subjectification; the complex ways in which technologies of self and technologies of domination are imbricated in the workings of the modern state; and finally the necessity of freedom.

Here the resonance with Spinoza is too strong to ignore. Spinoza too was concerned with the how humans organised themselves into a multitude capable of self-government. In the paper we have demonstrated the commonality between Foucault's opposition between power and resistance and Spinoza's distinction between constituted and constitutive power. Finally, for Spinoza, the idea of immanent causality was crucial to his critique of Hobbesian contract and sovereignty grounded in humanist individualism. In providing this comparison of Foucault and Spinoza we have shown that Foucault's discussions of power, resistance and the outside of thought did not simply carry over into his later thought. Rather he reworked them so that they became central to his idea of governmentality and his seemingly unrelated project of care of the self. The common ground in each case is an emancipatory reworking of the very "type of individuality that has been imposed on us for several centuries" (Foucault 1982, 790). 


\section{References}

Althusser, L. and Balibar, É., (1970), Reading Capital, (trans.) Ben Brewster, London: Verso.

Balibar, Étienne, (1985), Spinoza et la politique, Paris: Presses Universitaires de France.

Balibar, Étienne, (1989), 'Spinoza, The Anti-Orwell: Fear of the Masses' Rethinking Marxism, Fall, 2(3),

Barry, A., Osborne, T., \& Rose, N., 1996, eds, Foucault and Political Reason, London, University of UCL Press.

Brown, Wendy, 1995, States of Injury: Power and Freedom in Late Modernity, New Jersey, Princeton University Press.

Deleuze, G., (1968) Expressionism in Philosophy: Spinoza, trans. Martin Joughin (1990), New York: Zone.

Deleuze, Gilles, (1988), Spinoza: Practical Philosophy, trans. R. Hurley, San Francisco: City Lights.

Deleuze, Gilles, (1999), Foucault, trans. Sean Hand, London, Athlone Press.

Deleuze, G. and F. Guattari, (1994), What is Philosophy, Trans. H. Tomlinson and Graham Burchell, New York, Columbia University Press.

Dupont, D. \& Pearce, F., 2001, 'Foucault Contra Foucault: Rereading the "Governmentality" Papers', Theoretical Criminology, 5 (2), 123-58.

Foucault, M., 2000a, 'Security, Territory, and Population' in Ethics: Essential Works of Foucault 1954-1984, ed by Paul Rabinow, Volume 1 of three volumes, London, Penguin Books. pp. 67-71.

Foucault, M., 2000b, 'The Birth of Bio-Politics' in Ethics: Essential Works of Foucault 1954-1984, ed by Paul Rabinow, Volume 1 of three volumes, London, Penguin Books. pp. 73-80.

Foucault, M., 2000c, 'Sex, Power and the Politics of Identity' in Ethics: Essential Works of Foucault 1954-1984, ed by Paul Rabinow, Volume 1 of three volumes, London, Penguin Books. pp. 163-75.

Foucault, M., 2000d, 'The Ethics of the Concern for the Self as a Practice of Freedom' in Ethics: Essential Works of Foucault 1954-1984, ed by Paul Rabinow, Volume 1 of three volumes, London, Penguin Books. pp. 281-301.

Foucault, M., 1997a, 'What is Critique?' in The Politics of Truth, ed by S. Lotringer \& L. Hocbroth, New York: Semiotext(e). pp. 23-82.

Foucault, M., 1997b, "What Our Present Is" in The Politics of Truth, ed by S. Lotringer \& L. Hocbroth, New York: Semiotext(e). pp. 147-68.

Foucault, M., 1988, The Use of Pleasure: The History of Sexuality Volume 2, trans. Robert Hurley, Harmondsworth: Penguin Books.

Foucault, M., 1986a, 'Truth and Power' in Power/Knowledge: Selected Interviews and Other Writings 1972-77, ed by C. Gordon, trans by C. Gordon, L. Marshall, J. Mepham, K. Soper, Brighton, Harvester Press. pp. 109-33.

Foucault, M., 1986b, 'Power and Strategies' in Power/Knowledge: Selected Interviews and Other Writings 1972-77, ed by C. Gordon, trans. by C. Gordon, L. Marshall, J. Mepham, K. Soper, Brighton, Harvester Press. pp. 134-45.

Foucault, M., 1984, The History of Sexuality Volume 1: An Introduction, trans. Robert Hurley, Harmondsworth: Penguin Books. 
Foucault, M., 1983, This Is Not A Pipe, trans James Harkness, Berkeley, University of California Press.

Foucault, M., 1982, ‘The Subject and Power', Critical Inquiry, No. 8, pp. 777-95.

Foucault, M., 1981, 'Omnes et Singulatum: Towards A Criticism of "Political Reason", The Tanner Lectures on Human Values, II, ed S. M. McMurrin, Salt Lake City, University of Utah Press, 1981. pp. 225-54.

Foucault, M., 1979a, Discipline and Punish: The Birth of the Prison, trans. A. Sheridan, New York: Vintage Books.

Foucault, M., 1979b, 'Governmentality', Ideology \& Consciousness, No. 6, Summer. pp. 5-21.

Foucault, M., 1973, The Birth of the Clinic: An Archaeology of Medical Perception, trans. by A.M. Sheridan Smith, New York, Vintage Books.

Foucault, M., 1972, The Archaeology of Knowledge, trans. A.M. Sheridan Smith, London, Tavistock Publications.

Foucault, M., 1970, The Order of Things: An Archaeology of the Human Sciences, trans. from the French, London, Tavistock Publications.

Fourtounis, G., (2005), 'On Althusser's Immanentist Structuralism: Reading Montag Reading Althusser Reading Spinoza', Rethinking Marxism, January, 17( 1), 101118.

Guéroult, M., (1968), Spinoza, tome 1:Dieu (Ethique 1) Paris: Aubier.

Guéroult, M., (1974), Spinoza, tome 2: L’Ame (Ethique 2) Paris: Aubier.

Haas, L. 1998, 'Beheading the King: Foucault on the Limits of Juridical Thought' in Reinterpreting the Political: Continental Philosophy and Political Theory, ed by L. Langsdorf, S. H. Watson, \& K. Smith, Albany, State University of New York Press, 1998, 233-48.

Lemke, T., 2002, 'Foucault, Governmentality, and Critique', Rethinking Marxism, 14 (3), Fall, 49-64.

Lemke, T., 2001, “The Birth of Bio-Politics”: Michel Foucault's Lecture at the Collège de France on Neo-Liberal Governmentality', Economy and Society, 30 (2), May. pp. 190-207.

Macherey, P., (1979), Hegel ou Spinoza, Paris: Maspero.

Matheron, A., (1969), Individu et Communitauté chez Spinoza, Paris: Minuit

Matheron, A., (1971), Le Christ et le Salut des Ignorant chez Spinoza, Paris: Aubier.

Montag, W., (1989), 'Spinoza: Politics in a World without Transcendence', Rethinking Marxism, 2(3), 89-103.

Negri, A., (2004) Subversive Spinoza: (Un)contemporary Variations, Angelaki Humanities Series, Manchester: Manchester University Press,.

Negri, A., (1991), The Savage Anomaly: The Power of Spinoza's Metaphysics and Politics, trans. Michael Hardt, Minneapolis: University of Minnesota Press.

Rose, N., 1999, Powers of Freedom: Reframing Political Thought, Cambridge, Cambridge University Press.

Spinoza, B., (1996) Ethics, (ed. and trans, Edwin Curley), Penguin Books, Harmonsworth, Middlesex.

Thompson, K., 2003, 'Forms of Resistance: Foucault on Tactical Reversal and SelfFormation', Continental Philosophy, 36, 113-38. 


\section{Endnotes}

1 To clarify this conception Deleuze claims that for Descartes, the plane of immanence is "the subjective understanding presupposed by the 'I think' ", for Plato it is "the virtual image of an already-thought that doubles every actual concept", while for Heidegger, it is the "preontological understanding of Being".

2 In Difference and Repetition the site of transcendental illusion is representation, which takes on four forms with respect to the four-fold medieval distinction between sensibility, thought, the idea, and being. These iron collars of representation are (a) identity in the concept (ratio cognoscendi); (b) opposition in the predicate (ratio fiendi); (c) analogy in the judgement (ratio essendi); and, (d) resemblance in perception (ratio agendi). 